\title{
Tissue Distribution and Biochemical Changes in Response to Copper Accumulation in Erica australis L.
}

\author{
Daniel Trigueros and Sabina Rossini-Oliva *(D) \\ Department of Plant Biology and Ecology, University of Seville, Avda. Reina Mercedes s/n, P.O. Box 1095, \\ 41012 Seville, Spain; biodtv@hotmail.com \\ * Correspondence: sabina@us.es
}

check for updates

Citation: Trigueros, D.;

Rossini-Oliva, S. Tissue Distribution and Biochemical Changes in Response to Copper Accumulation in Erica australis L. Plants 2021, 10, 1428. https://doi.org/10.3390/ plants10071428

Academic Editor: Othmane Merah

Received: 25 May 2021

Accepted: 8 July 2021

Published: 13 July 2021

Publisher's Note: MDPI stays neutral with regard to jurisdictional claims in published maps and institutional affiliations.

Copyright: (c) 2021 by the authors. Licensee MDPI, Basel, Switzerland. This article is an open access article distributed under the terms and conditions of the Creative Commons Attribution (CC BY) license (https:/ / creativecommons.org/licenses/by/ $4.0 /)$.

\begin{abstract}
Copper uptake, accumulation in different tissues and organs and biochemical and physiological parameters were studied in Erica australis treated with different $\mathrm{Cu}$ concentrations $(1,50,100$ and $200 \mu \mathrm{M}$ ) under hydroponic culture. Copper treatments led to a significant reduction in growth rate, biomass production and water content in shoots, while photosynthetic pigments did not change. Copper treatments led to an increase in catalase and peroxidase activities. Copper accumulation followed the pattern roots $>$ stems $\geq$ leaves, being roots the prevalent $\mathrm{Cu}$ sink. Analysis by scanning electron microscopy coupled with elemental X-ray analysis (SEM-EDX) showed a uniform Cu distribution in root tissues. On the contrary, in leaf tissues, $\mathrm{Cu}$ showed preferential storage in abaxial trichomes, suggesting a mechanism of compartmentation to restrict accumulation in mesophyll cells. The results show that the studied species act as a Cu-excluder, and $\mathrm{Cu}$ toxicity was avoided to a certain extent by root immobilization, leaf tissue compartmentation and induction of antioxidant enzymes to prevent cell damage.
\end{abstract}

Keywords: tolerance; Ericaceae; mining; toxicity

\section{Introduction}

A heavy metal such as $\mathrm{Cu}$ is an essential nutrient being required for normal plant growth for several biochemical processes as a constituent of enzymes and proteins. However, a high $\mathrm{Cu}$ concentration in the soil resulting in toxicity levels may occur when parental materials have been $\mathrm{Cu}$-rich, and soil $\mathrm{pH}$ favors metal availability, or polluted by mining activities and waste deposits, or in agricultural soils by intensive use of $\mathrm{Cu}$-containing compounds for plant disease control or heavy application of manure or sewage sludge $[1,2]$. The critical toxicity level for most crops is above $20-30 \mathrm{mg} \mathrm{kg}^{-1}$ leaf dry weight [3], while in $\mathrm{Cu}$-tolerant metallophytes, leaves may contain up to $1000 \mu \mathrm{g} \mathrm{g}^{-1}$ leaf dry weight $[4,5]$. Leaf chlorosis and stunted growth are the more frequent copper toxicity symptoms observed mostly as the result of inhibition of nutrient uptake or direct interference with plant metabolism $[2,6]$.

A significant body of knowledge about heavy metal tolerance in plants has been acquired from the study of species thriving in the harsh environments of abandoned mines $[3,7,8]$. In the Iberian Pyrite Belt, a sulphide mining area of southern Portugal and SW Spain, Erica australis shares habitat with E. andevalensis while growing on highly acidic and heavy-metals polluted soils [9-11]. In these soils, $\mathrm{Cu}$ appears at a concentration of up to $1400 \mathrm{mg} \mathrm{kg}^{-1}$ [11]. However, plant species growing in such contaminated soils hardly reach toxic $\mathrm{Cu}$ concentration in their tissues $[9,11,12]$.

The (first barrier) main strategy to tolerate heavy metal stress is to reduce metal uptake and transport by root fixation or complexation at the rhizosphere [3,7]. If high $\mathrm{Cu}$ levels reach the leaves, the metal has to be complexed and stored in vacuoles to avoid the production of reactive oxygen species (ROS). Meanwhile, increased activity of ROS scavenging systems is induced to cope with free radicals, which might generate protein damage by oxidative stress [13]. Organic compounds such as amino acids, amides and 
carboxylates, of known metal-complexing properties are synthesized in response to metallic stresses [6]. However, their roles in metal tolerance still need to be proved in many species.

Some of these mechanisms related to the $\mathrm{Cu}$ tolerance, such as metal fixation in roots, induction of antioxidant systems and increased in organic complexing compounds, have been described for E. andevalensis [14]. However, E. australis colonizes much wider areas in the same polluted soils of Riotinto. Might it be because of differential sensitivity to metal excess or greater nutrient use efficiency? The aim of the present work was to study how an excess of $\mathrm{Cu}$ in E. australis might affect plant growth and biochemical parameters in comparison with other species that successfully thrive on heavy metal polluted soils.

\section{Results}

Copper treatments negatively affected plant growth and biomass production (Figure 1, Table 1). The growth of control plants followed an exponential model $\left(R^{2}=0.979\right.$; $\mathrm{y}=99 \times \mathrm{e}^{0.023 \mathrm{t}}$ ) while in those plants treated with $50 \mu \mathrm{M} \mathrm{Cu}$, growth followed a linear relationship with time $\left(R^{2}=0.753 ; y=99+1.24 \times t\right)$. When plants were treated with $100 \mu \mathrm{M} \mathrm{Cu}$, they stop growing after 10 days of treatment, while at $200 \mu \mathrm{M} \mathrm{Cu}$, plants lost weight progressively, and biomass significantly decreased in both 100 and $200 \mu \mathrm{M} \mathrm{Cu}$ treatments. Darkened roots and wilted and bronzing leaves were observed in plants at the highest $\mathrm{Cu}$ concentration. A significant reduction in biomass was also observed when plants were treated with $50 \mu \mathrm{M} \mathrm{Cu}$ comparing with control (Table 1). A negative effect was observed between $\mathrm{Cu}$ treatments and shoot and root water contents (Figure 2), and the decrease in water content in all $\mathrm{Cu}$ treatments was statistically significant with respect to the control $(p<0.05)$. This decrease was more remarkable in shoots at the highest $\mathrm{Cu}$ concentration. The shoot/root ratio was not different among $\mathrm{Cu}$ treatments (Figure 3, $p>0.005$ ). The malondialdehyde (MDA) content, as a marker of lipid peroxidation, was similar in roots from all treatments (Table 1), while in leaves, an increasing trend in MDA contents was observed, and a significant difference was found in MDA contents in leaves from plants cultivated at the highest $\mathrm{Cu}$ concentration. Catalase activity in the roots also significantly increased at 100 and $200 \mu \mathrm{M} \mathrm{Cu}$ concentrations. An increase in peroxidase (POD) activity in roots was found at $100 \mu \mathrm{M} \mathrm{Cu}$, but POD activity decreased in plants cultivated at the highest $\mathrm{Cu}$ concentration (Table 1). Photosynthetic pigments were differently affected by $\mathrm{Cu}$ treatments (Table 1 ). The content of chlorophylls showed no differences among $\mathrm{Cu}$ treatments, whereas the content of carotenoids decreased only at the highest $\mathrm{Cu}$ concentration.

The $\mathrm{Cu}$ accumulation in the different organs (Table 2) followed the same pattern in control and treated plants (roots $>$ stems $\geq$ leaves). Copper concentration in roots, stems and leaves (y) increased exponentially with $\mathrm{Cu}$ treatments $(\mathrm{x})$ up to $100 \mu \mathrm{M} \mathrm{Cu}$ $\left(y=a \times e^{b x}\right.$; Table 2). In the roots, $\mathrm{Cu}$ concentration also increased at the highest $\mathrm{Cu}$ treatment $(p=0.011)$, while in stems and leaves, the increase was not significant at $200 \mu \mathrm{M} \mathrm{Cu}$ concentration $(p>0.05)$. The concentration of macro and micronutrients in leaves, stems and roots is shown in Table 3. Copper treatments did not lead to mineral deficiencies in leaves, and a positive correlation was found between $\mathrm{Cu}$ treatment and almost all macro and micronutrients (Table 4). A similar trend was observed in roots except for $\mathrm{K}$, where $\mathrm{Cu}$ showed an antagonist effect on root $\mathrm{K}$ content. 


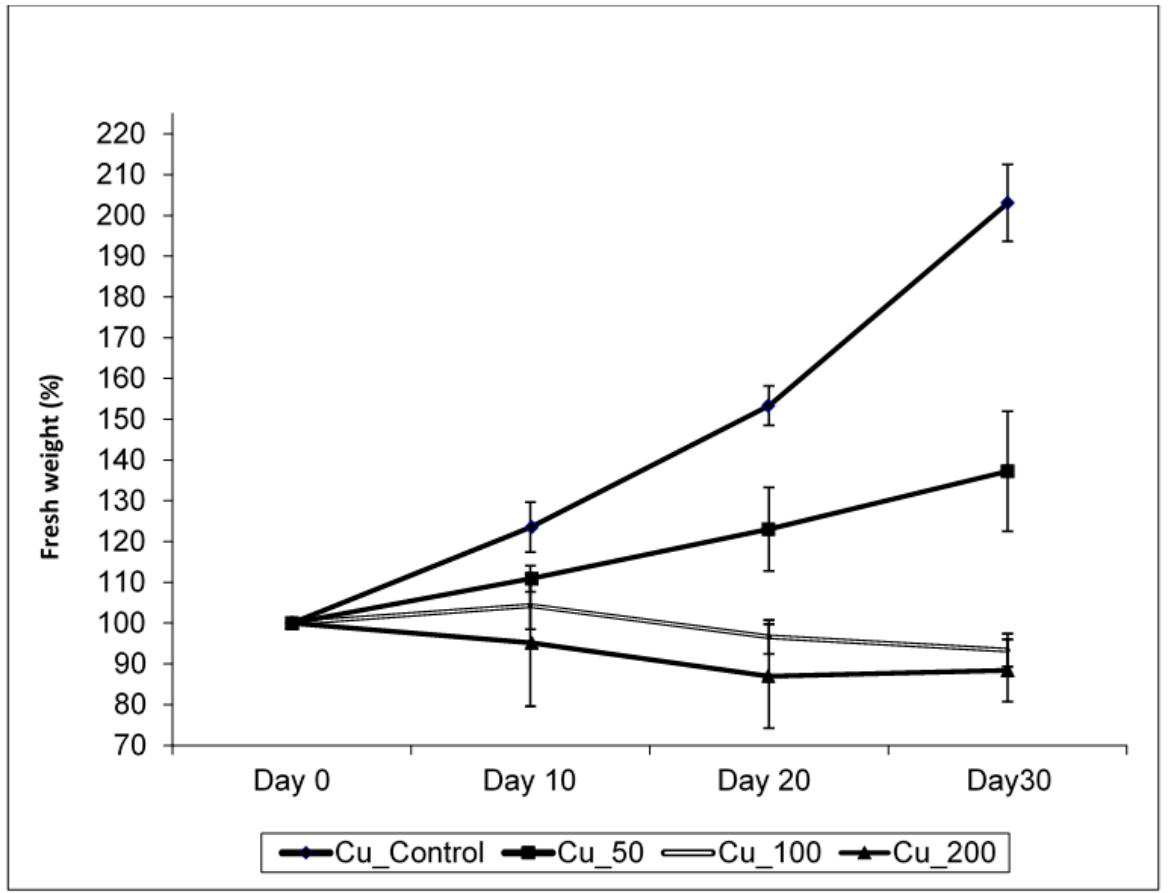

Figure 1. The effect of $\mathrm{Cu}$ treatments on growth in Erica australis plants (mean \pm standard deviation, $n=4)$.

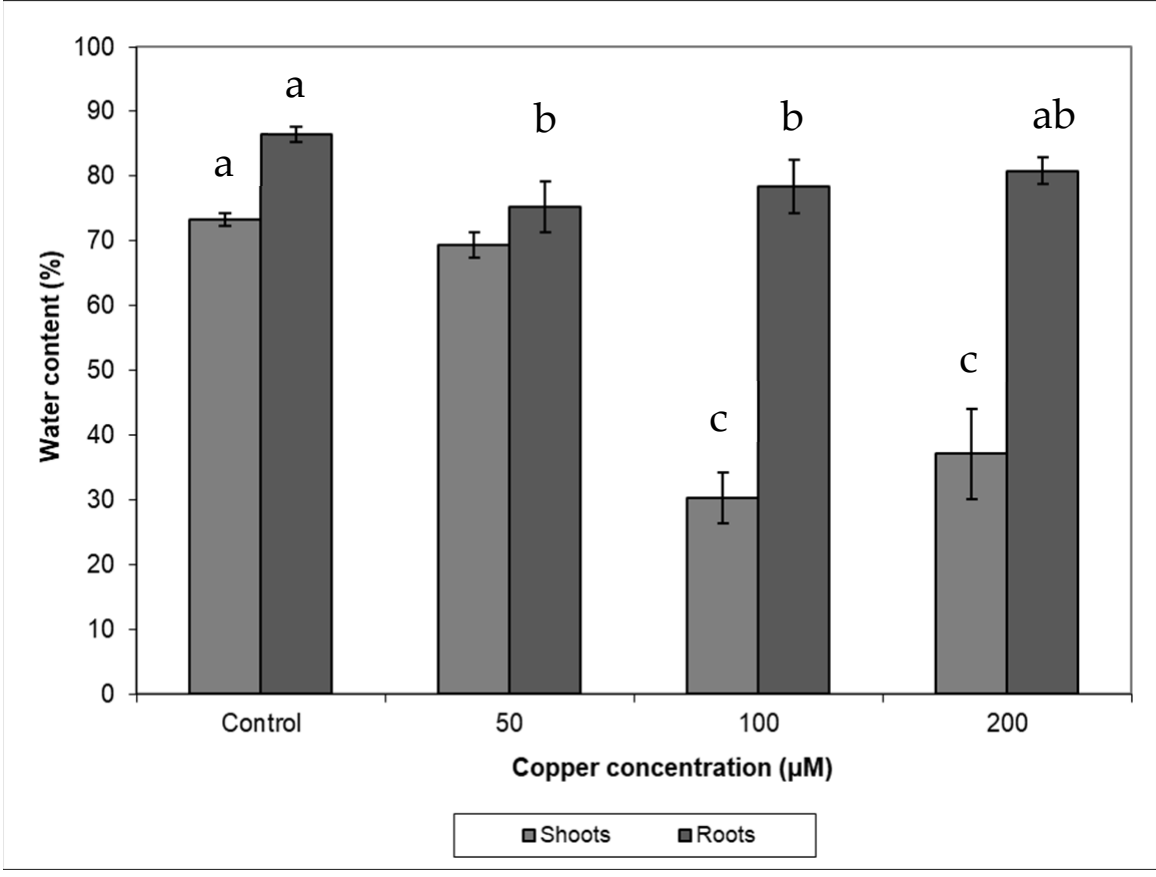

Figure 2. The water content in plants of Erica australis subjected to different $\mathrm{Cu}$ treatments (mean \pm standard deviations, $n=4$ ). Different letters indicate significant differences between groups (ANOVA, post hoc Tukey test, $p<0.05)$. 
Table 1. Biomass, photosynthetic pigments and biochemical parameters measured in Erica australis treated with different $\mathrm{Cu}$ concentrations (mean \pm standard deviation).

\begin{tabular}{|c|c|c|c|c|c|c|c|c|}
\hline \multirow[t]{2}{*}{$\begin{array}{c}\mathrm{Cu} \\
(\mu \mathrm{M})\end{array}$} & \multirow[t]{2}{*}{$\begin{array}{c}\text { Biomass } \\
(\mathrm{g})\end{array}$} & \multirow[b]{2}{*}{ Leaf } & \multirow{2}{*}{$\begin{array}{c}\begin{array}{c}\text { MDA } \\
(\mathrm{nmol} / \mathrm{g} \text { Fw })\end{array} \\
\text { Root }\end{array}$} & \multicolumn{2}{|c|}{$\begin{array}{c}\text { EA Root } \\
\text { (U/mg Proteins) }\end{array}$} & \multicolumn{3}{|c|}{$\begin{array}{l}\text { Pigments } \\
(\mu g / g \text { Fw })\end{array}$} \\
\hline & & & & CAT & POD & Chl.a & Chl.b & Carotenoids \\
\hline 1 (Control) & $3.05 \pm 0.85 \mathrm{a}$ & $295 \pm 24.1 \mathrm{a}$ & $45.4 \pm 31.4 \mathrm{a}$ & $<$ l.d. & $3.20 \pm 0.17 \mathrm{a}$ & $1548 \pm 598 \mathrm{a}$ & $480 \pm 232 \mathrm{a}$ & $317 \pm 59.2 \mathrm{ab}$ \\
\hline 50 & $1.15 \pm 0.73 b$ & $425 \pm 284 \mathrm{a}$ & $24.5 \pm 20.8 \mathrm{a}$ & $<$ l.d. & $1.25 \pm 0.23 b$ & $1101 \pm 38 \mathrm{a}$ & $341 \pm 11.3 \mathrm{a}$ & $225 \pm 6.20 \mathrm{bc}$ \\
\hline 100 & $-0.17 \pm 0.73 c$ & $366 \pm 51.4 \mathrm{a}$ & $5.59 \pm 5.0 \mathrm{a}$ & $59.7 \pm 16.6 \mathrm{a}$ & $3.91 \pm 0.10 \mathrm{c}$ & $1623 \pm 23 \mathrm{a}$ & $536 \pm 13.8 \mathrm{a}$ & $400 \pm 41.1 \mathrm{a}$ \\
\hline 200 & $-0.32 \pm 0.25 c$ & $1668 \pm 483 b$ & $11.7 \pm 0.32 \mathrm{a}$ & $91.6 \pm 5.65 b$ & $0.49 \pm 0.14 \mathrm{~d}$ & $1071 \pm 362 \mathrm{a}$ & $694 \pm 172 \mathrm{a}$ & $105 \pm 70.2 c$ \\
\hline
\end{tabular}

MDA, malondialdehyde; EA root, enzymatic activities in roots; CAT, catalase; POD, peroxidase; Chl.a, chlorophyll a; Chl.b, chlorophyll b; 1.d., detection limit; Fw, fresh weight. Different letters indicate statistical differences between treatments.

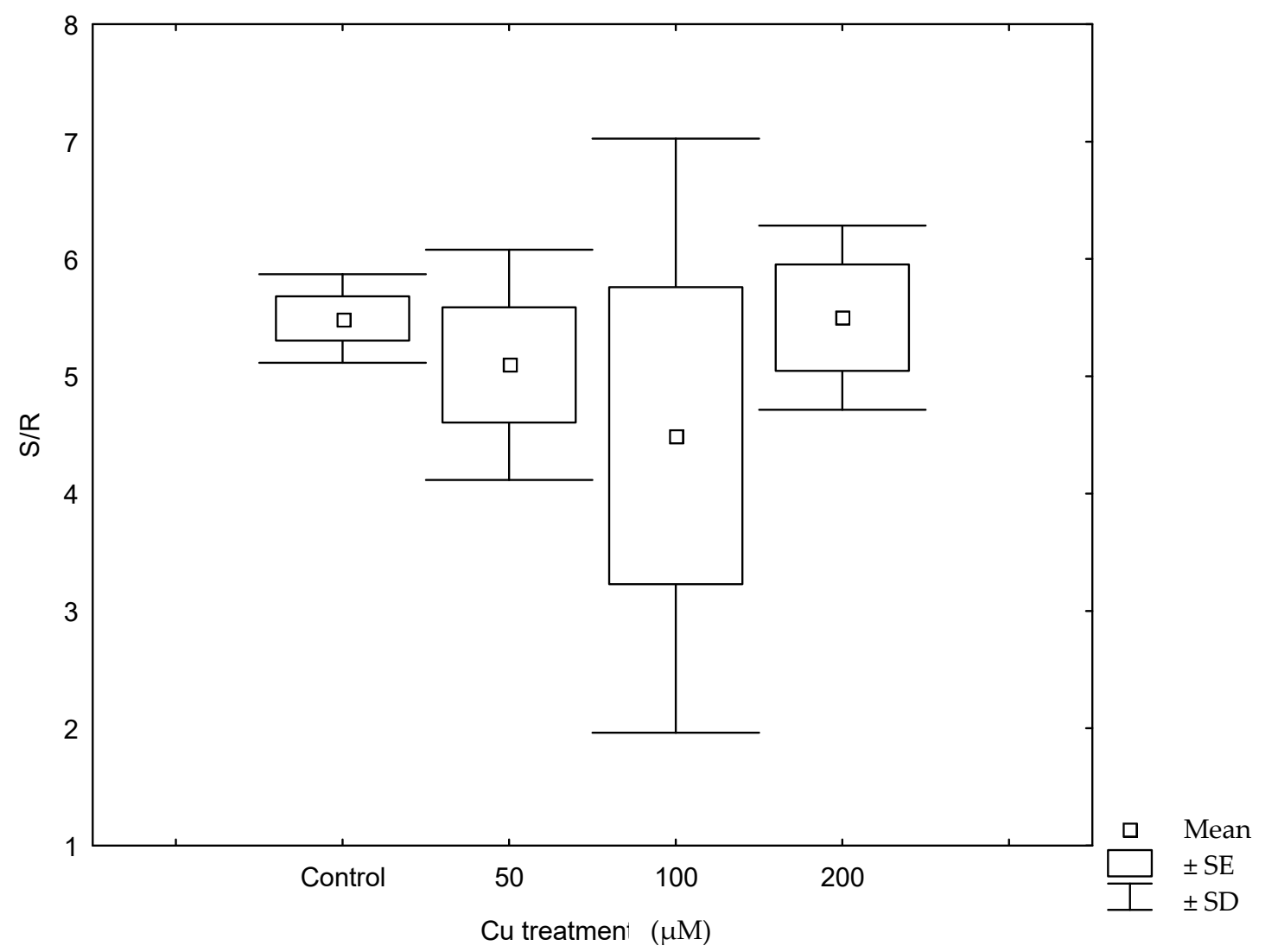

Figure 3. The shoot/root ratio (S/R) in plants of Erica australis after 30 days of growth in nutrient solutions with different $\mathrm{Cu}$ concentrations. SE, standard error.

Table 2. The copper concentration (mean \pm standard deviation; $\mathrm{mg} / \mathrm{kg}$ ) in Erica australis $(n=4)$ treated with Cu. Regression coefficients $(a, b) \pm$ standard deviation.

\begin{tabular}{cccccccc}
\hline & \multicolumn{4}{c}{ Cu Treatments $(\boldsymbol{\mu M})$} & \multicolumn{3}{c}{ Regression (1-100 $\boldsymbol{\mu M})$} \\
\cline { 2 - 8 } & $\mathbf{1}$ (Control) & $\mathbf{5 0}$ & $\mathbf{1 0 0}$ & $\mathbf{2 0 0}$ & $\mathbf{R}^{\mathbf{2}}$ & $\mathbf{a}$ & $\mathbf{b}$ \\
\hline Leaf & $4.55 \pm 1.41$ & $24.9 \pm 4.47$ & $58.3 \pm 17.8$ & $50.5 \pm 26.5$ & 0.913 & $5.0 \pm 0.8$ & $0.026 \pm 0.003$ \\
Stem & $3.94 \pm 0.30$ & $27.8 \pm 5.80$ & $182 \pm 98.1$ & $170 \pm 115$ & 0.954 & $4.0 \pm 0.7$ & $0.037 \pm 0.003$ \\
Root & $22.5 \pm 4.55$ & $804 \pm 196$ & $3738 \pm 288$ & $5978 \pm 1380$ & 0.943 & $30 \pm 8$ & $0.052 \pm 0.004$ \\
\hline
\end{tabular}


Table 3. The concentration of macro and micronutrients in leaves, stems and roots of Erica australis plants grown in nutrient solutions with different $\mathrm{Cu}$ treatments $(n=4) .1 \mu \mathrm{M}=$ Control.

\begin{tabular}{|c|c|c|c|c|c|c|c|c|c|c|c|c|}
\hline $\begin{array}{c}\mathrm{Cu} \\
\text { Treatments } \\
(\mu \mathrm{M})\end{array}$ & Organs & & $\begin{array}{c}B \\
(\mathrm{mg} / \mathrm{kg})\end{array}$ & Ca $(\%)$ & $\begin{array}{c}\text { Fe } \\
(\mathrm{mg} / \mathrm{kg})\end{array}$ & K (\%) & $\begin{array}{l}\mathrm{Mg} \\
(\%)\end{array}$ & $\begin{array}{c}\text { Mn } \\
(\mathrm{mg} / \mathrm{kg})\end{array}$ & $\begin{array}{c}\mathrm{Na} \\
(\mathrm{mg} / \mathrm{kg})\end{array}$ & $P(\%)$ & S (\%) & $\begin{array}{c}\mathrm{Zn} \\
(\mathrm{mg} / \mathrm{kg})\end{array}$ \\
\hline \multirow{9}{*}{1} & \multirow{3}{*}{ Leaves } & Mean & 74.0 & 0.20 & 81.0 & 1.65 & 0.20 & 114.5 & 327.00 & 0.50 & 0.17 & 13.5 \\
\hline & & Median & 74.0 & 0.22 & 88.0 & 1.59 & 0.20 & 119.5 & 336.50 & 0.48 & 0.17 & 13.5 \\
\hline & & St. Dev & 14.8 & 0.06 & 21.0 & 0.25 & 0.03 & 18.6 & 49.27 & 0.21 & 0.02 & 0.6 \\
\hline & \multirow{3}{*}{ Stems } & Mean & 27.5 & 0.14 & 45.5 & 1.99 & 0.14 & 113.3 & 378.00 & 0.47 & 0.07 & 10.5 \\
\hline & & Median & 28.5 & 0.15 & 44.0 & 1.98 & 0.14 & 113.5 & 360.50 & 0.46 & 0.07 & 10.5 \\
\hline & & St. Dev. & 6.1 & 0.03 & 13.6 & 0.04 & 0.02 & 26.0 & 57.18 & 0.09 & 0.00 & 1.3 \\
\hline & \multirow{3}{*}{ Roots } & Mean & 16.7 & 0.17 & 2831.5 & 1.59 & 0.11 & 86.8 & 706.00 & 0.69 & 0.16 & 33.3 \\
\hline & & Median & 15.0 & 0.16 & 2828.5 & 1.56 & 0.11 & 83.5 & 670.00 & 0.68 & 0.17 & 34.0 \\
\hline & & St. Dev. & 2.9 & 0.05 & 316.1 & 0.14 & 0.02 & 13.9 & 148.84 & 0.09 & 0.02 & 7.7 \\
\hline \multirow{9}{*}{50} & \multirow{3}{*}{ Leaves } & Mean & 63.3 & 0.25 & 74.3 & 1.77 & 0.21 & 109.5 & 444.00 & 0.39 & 0.22 & 19.0 \\
\hline & & Median & 64.0 & 0.25 & 67.0 & 1.79 & 0.21 & 111.5 & 444.50 & 0.39 & 0.22 & 18.0 \\
\hline & & St. Dev. & 5.9 & 0.03 & 16.6 & 0.16 & 0.02 & 13.7 & 83.45 & 0.05 & 0.02 & 2.0 \\
\hline & \multirow{3}{*}{ Stems } & Mean & 21.3 & 0.19 & 24.3 & 1.62 & 0.12 & 87.8 & 434.00 & 0.44 & 0.09 & 10.8 \\
\hline & & Median & 21.0 & 0.17 & 24.0 & 1.66 & 0.12 & 86.5 & 417.50 & 0.43 & 0.09 & 11.0 \\
\hline & & St. Dev. & 5.5 & 0.04 & 3.5 & 0.21 & 0.02 & 18.8 & 47.66 & 0.07 & 0.01 & 0.5 \\
\hline & \multirow{3}{*}{ Roots } & Mean & 22.8 & 0.36 & 14291 & 1.14 & 0.13 & 89.0 & 950.75 & 1.05 & 0.21 & 47.7 \\
\hline & & Median & 23.5 & 0.26 & 13720 & 1.15 & 0.13 & 91.0 & 886.00 & 1.05 & 0.20 & 48.0 \\
\hline & & St. Dev. & 3.6 & 0.26 & 3189 & 0.13 & 0.01 & 7.2 & 344.99 & 0.20 & 0.02 & 0.6 \\
\hline \multirow{9}{*}{100} & \multirow{3}{*}{ Leaves } & Mean & 80.8 & 0.55 & 118.5 & 2.73 & 0.30 & 169.8 & 751.00 & 0.51 & 0.43 & 20.8 \\
\hline & & Median & 78.5 & 0.56 & 117.5 & 2.69 & 0.30 & 169.5 & 705.50 & 0.50 & 0.42 & 20.5 \\
\hline & & St. Dev. & 11.4 & 0.14 & 18.9 & 0.46 & 0.03 & 14.1 & 160.32 & 0.02 & 0.12 & 2.1 \\
\hline & \multirow{3}{*}{ Stems } & Mean & 21.0 & 0.23 & 40.7 & 2.06 & 0.11 & 85.5 & 750.25 & 0.46 & 0.19 & 18.8 \\
\hline & & Median & 21.0 & 0.20 & 37.0 & 2.00 & 0.12 & 87.5 & 718.50 & 0.45 & 0.19 & 18.0 \\
\hline & & St. Dev. & 7.5 & 0.07 & 7.2 & 0.39 & 0.02 & 10.7 & 219.64 & 0.07 & 0.03 & 7.9 \\
\hline & \multirow{3}{*}{ Roots } & Mean & 48.8 & 0.63 & 37239 & 0.73 & 0.21 & 157.5 & 1579.25 & 1.87 & 0.24 & 53.0 \\
\hline & & Median & 49.0 & 0.67 & 36855 & 0.69 & 0.21 & 155.5 & 1605.50 & 1.99 & 0.24 & 52.0 \\
\hline & & St. Dev. & 3.8 & 0.23 & 2403 & 0.11 & 0.07 & 49.3 & 242.39 & 0.44 & 0.03 & 5.3 \\
\hline \multirow{9}{*}{200} & \multirow{3}{*}{ Leaves } & Mean & 75.2 & 0.27 & 80.7 & 1.62 & 0.20 & 110.0 & 650.17 & 0.46 & 0.22 & 20.8 \\
\hline & & Median & 87.0 & 0.26 & 73.5 & 1.52 & 0.20 & 98.5 & 628.00 & 0.45 & 0.21 & 16.5 \\
\hline & & St. Dev. & 20.7 & 0.05 & 20.0 & 0.29 & 0.02 & 34.3 & 165.09 & 0.09 & 0.03 & 9.6 \\
\hline & \multirow{3}{*}{ Stems } & Mean & 40.7 & 0.16 & 124.2 & 1.60 & 0.09 & 81.0 & 852.40 & 0.48 & 0.14 & 19.7 \\
\hline & & Median & 43.0 & 0.15 & 124.0 & 1.62 & 0.09 & 60.5 & 864.00 & 0.49 & 0.15 & 20.0 \\
\hline & & St. Dev. & 7.2 & 0.02 & 15.2 & 0.40 & 0.04 & 52.1 & 91.30 & 0.06 & 0.05 & 6.4 \\
\hline & \multirow{3}{*}{ Roots } & Mean & 90.0 & 0.51 & 62856 & 0.92 & 0.17 & 191.0 & 2752.50 & 3.73 & 0.37 & 132.0 \\
\hline & & Median & 90.0 & 0.49 & 63189 & 0.89 & 0.14 & 167.0 & 2551.50 & 3.47 & 0.31 & 116.0 \\
\hline & & St. Dev. & 0.0 & 0.12 & 8651 & 0.31 & 0.07 & 71.1 & 489.14 & 0.81 & 0.12 & 48.5 \\
\hline
\end{tabular}

Table 4. The Pearson correlation $(p<0.05)$ between the $\mathrm{Cu}$ concentration and the other elements in different plant parts of Erica australis $(n \geq 16)$.

\begin{tabular}{cccccccccc}
\hline & \multicolumn{4}{c}{ Macronutrients } & \multicolumn{5}{c}{ Micronutrients } \\
\cline { 2 - 10 } & $\mathbf{P}$ & $\mathbf{K}$ & $\mathbf{S}$ & $\mathbf{M g}$ & $\mathbf{C a}$ & $\mathbf{F e}$ & $\mathbf{M n}$ & $\mathbf{B}$ & $\mathbf{Z n}$ \\
\hline Leaves & - & 0.607 & 0.751 & 0.643 & 0.696 & 0.484 & 0.641 & - & 0.550 \\
Stems & - & - & 0.848 & - & & - & - & - & 0.605 \\
Roots & 0.960 & -0.558 & 0.889 & 0.591 & 0.577 & 0.982 & 0.843 & 0.939 & 0.809 \\
\hline
\end{tabular}

Morphologically, Erica australis presents small leaves with strongly revoluted margins (Figure 4A) and an epidermis covered by a thick cuticle and pluricellular and glandular trichomes (Figure 4B). The Cu content (weight \%) in the different leaf tissues obtained by cryo-SEM/EDX is shown in Figure 5. The leaf adaxial trichomes (hair) accumulated significantly more $\mathrm{Cu}$ than other leaf tissues like parenchyma cells or epidermis. In the roots, $\mathrm{Cu}$ was homogeneously distributed in epidermal cells, cortex and vascular tissues $(p>0.05)$. 


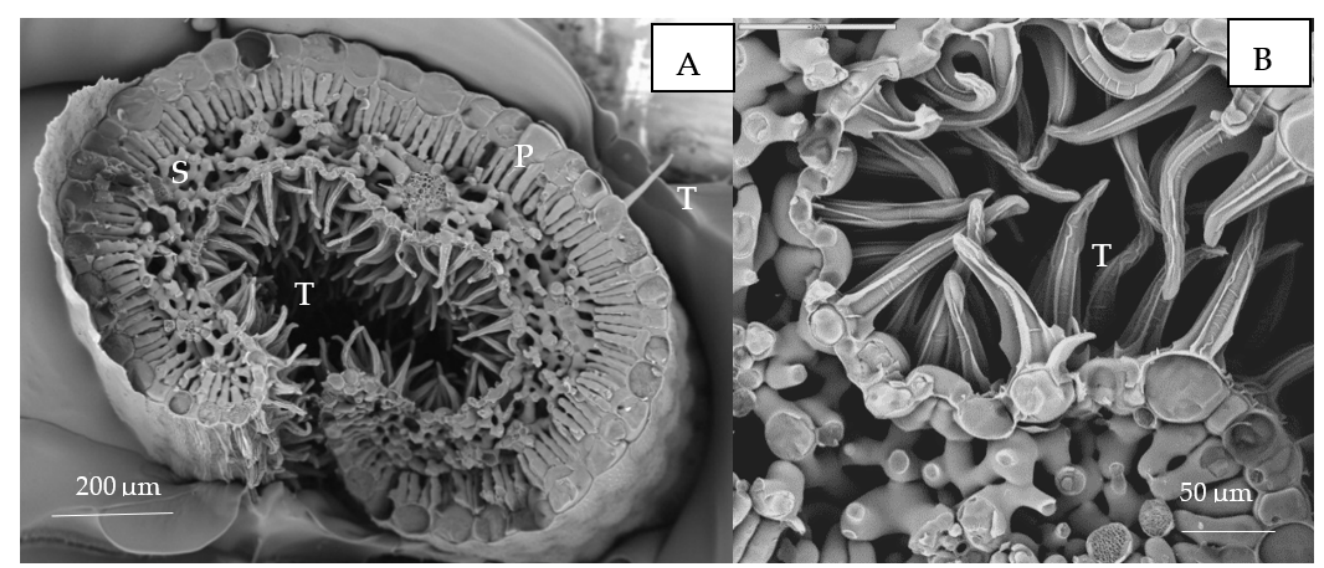

Figure 4. Leaves of Erica australis treated with $50 \mu \mathrm{M} \mathrm{Cu}$ by SEM observations. (A) Details of palisade (P) and spongy mesophyll (S) and adaxial trichomes (T); (B) Abaxial surface with trichomes (T).

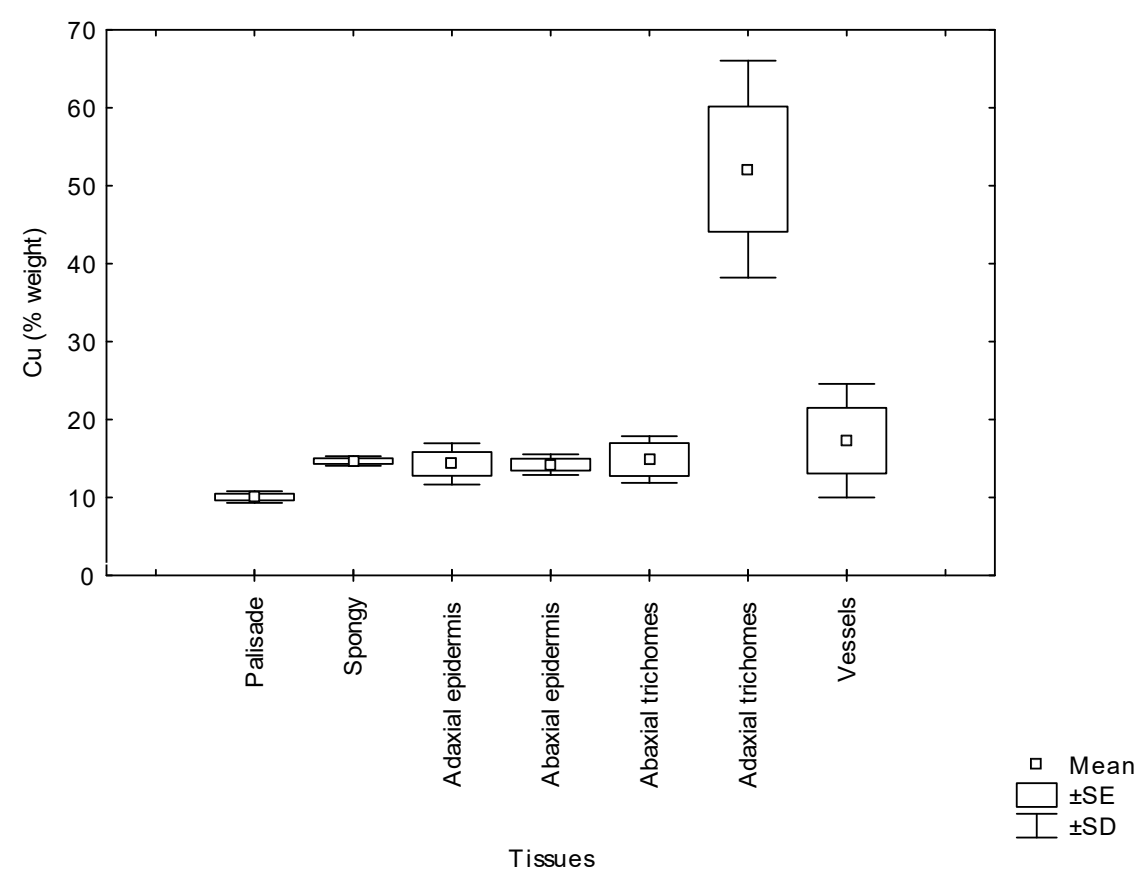

Figure 5. The copper concentration (\% weight mean $\pm \mathrm{SD})$ in leaves tissues of Erica australis grown in culture solution added with $50 \mu \mathrm{M} \mathrm{Cu}$. SE; standard error.

\section{Discussion}

Erica australis colonize the abandoned mining area of Riotinto, one of the most extensive examples of an extremely acidic environment [15] where soils are considerably contaminated by $\mathrm{Cu}$ [12]. In controlled conditions, plants survived at $200 \mu \mathrm{M} \mathrm{Cu}$ concentration in the medium but did not grow, and their leaves lost turgor as a consequence of decreased water uptake. At $250 \mu \mathrm{M} \mathrm{Cu}$, the plants died after 20 days (personal observation). The root is the organ in direct contact with metal ions in the growth medium, and the accumulation pattern showed that $\mathrm{Cu}$ was almost immobilized in roots (Table 2). This is the most common mechanism of metal tolerance of metallophytes, which restricts metal transport into aerial parts [16]. In plants treated with the highest $\mathrm{Cu}$ concentration, the root $\mathrm{Cu}$ content was very high $\left(5978 \mathrm{mg} \mathrm{kg}^{-1}\right)$ compared with the $\mathrm{Cu}$ found in the root cortex of E. australis growing in the Riotinto mining area [12]. As presented in Table 2, similar values of root $\mathrm{Cu}$ concentrations have been reported by Monni et al. [4] in another species of Ericaceae under $\mathrm{Cu}$ treatments, but in contrast to our results, the plants showed a mortality rate of $60 \%$. 
The cryo-SEM/EDX analysis in the roots of $\mathrm{Cu}$-treated plants revealed that $\mathrm{Cu}$ was uniformly localized among cortex, vascular tissues and rizodermis, but it is possible that $\mathrm{Cu}$ remained compartmentalized in the cell walls or vacuoles as was suggested as a strategy to cope with absorbed $\mathrm{Cu}[2,17,18]$. Other mechanisms such as $\mathrm{Cu}$ accumulation in cytoplasmic vesicles are also observed [17]. High $\mathrm{Cu}$ concentration damage epidermal cells, reducing mitochondria and inducing cortical cell death [17]. There are gene families that play a key role in controlling $\mathrm{Cu}$ stress [19], and some of them are related to actin and cytoskeleton formation, metal transporters and superoxide dismutase activity in root tissues [20]. The root tissues of rice seedlings accumulate over $40 \%$ of the $\mathrm{Cu}$ present in the medium, and $60 \%$ of it was not fully available for transport [21].

Under field conditions, Monaci et al. [12] found that leaf $\mathrm{Cu}$ concentration in E. australis from Riotinto was similar to the values found in the control plants (grown on noncontaminated soils, $4.62 \mathrm{mg} \mathrm{Cu} \mathrm{kg}{ }^{-1}$ ), despite the high content of $\mathrm{Cu}$ in Riotinto soils (158 mg Cu kg ${ }^{-1}$ ). Their results showed the species was able to avoid $\mathrm{Cu}$ translocation from roots to leaves. Our results under controlled conditions demonstrate that the species was able to control upward transport of $\mathrm{Cu}$ as leaf metal concentration was only $3.5-6.5 \%$ of total $\mathrm{Cu}$ translocated to the shoots. In spite of this, $\mathrm{Cu}$ concentration in $\mathrm{Cu}$-treated plants reached values higher than the normal concentration $\left(10 \mathrm{mg} \mathrm{kg}^{-1}\right)$ [22] or levels considered toxic (above $20-30 \mathrm{mg} \mathrm{kg}^{-1}$, 3). Some species can tolerate greater metal concentration in leaves, reaching up to 100 and $180 \mathrm{mg} \mathrm{kg}^{-1} \mathrm{Cu}$ [23]. In the Riotinto mining area, the maximum leaf $\mathrm{Cu}$ concentration found in this species was $6.57 \mathrm{mg} \mathrm{kg}^{-1}$ [24]. Different environmental conditions and root colonization by mycorrhiza might play a role in metal tolerance. Even if the roots continued accumulating $\mathrm{Cu}$ at the highest $\mathrm{Cu}$ treatment, in the shoots, the $\mathrm{Cu}$ concentration did not increase further after $100 \mu \mathrm{M} \mathrm{Cu}$ (Table 2). A similar pattern was observed in Avicennia marina, where root structure alteration was not observed as a general symptom of $\mathrm{Cu}$ toxicity but darkened roots observed in plants cultivated at $200 \mu \mathrm{M}$ Cu might indicate necrosis [2]. Root anatomical and physiological alterations play an important role in metal transport and plant growth $[6,25]$. The high $\mathrm{Cu}$ concentration in roots was responsible for the inhibition in plants growth and biomass production as a consequence of $\mathrm{Cu}$ toxicity. In fact, changes in biomass and in growth parameters have been indicators frequently used to test $\mathrm{Cu}$ toxicity $[13,26,27]$. Shoots showed similar sensitivity to roots to high $\mathrm{Cu}$ concentration in the nutrient solution (Figure 3 ). The reduction in biomass might be the result of damages produced by $\mathrm{Cu}$ stress in cell membranes by the increase in the $\mathrm{H}_{2} \mathrm{O}_{2}$ level that causing lipid peroxidation and further damages in organelles, nucleic acids, proteins and carbohydrates $[13,28,29]$. The shoot and root water content decreased significantly in plants treated with $\mathrm{Cu}$ (Figure 2). This was particularly remarkable in leaves from plants at the highest $\mathrm{Cu}$ concentration reflecting the metal interference in root water uptake and transport. The lower water contents in the aerial parts might be related to the reduced root growth and/or a consequence of changes induced in water transport proteins [30,31] and direct damages of root cell membranes [32].

Macro and micronutrients contents in shoots and roots tissues were not very much affected by $\mathrm{Cu}$ stress as it has been published for other species $[2,4,14,33]$. The exception was root $\mathrm{K}$ content, whose reduction might be related to membrane damage in root cells (see Table 3). The lack of antagonistic effects of $\mathrm{Cu}$ over other mineral nutrients might be another strategy of this species to cope with $\mathrm{Cu}$ toxicity.

On the other hand, in the leaves, the high $\mathrm{Cu}$ concentration did not affect photosynthetic pigment contents such as chlorophyll $\mathrm{a}$ and $\mathrm{b}$ (Table 1). Chlorosis was not observed in any of the $\mathrm{Cu}$ treatments in spite of being a frequent symptom of $\mathrm{Cu}$ toxicity in other plants [3,34]. In fact, nutrient elements, such as Fe and $\mathrm{Mg}$, whose $\mathrm{Cu}$-induced deficiency caused chlorosis [3], increased in leaves from Cu-treated plants. Certainly, the accumulation of $\mathrm{Cu}$ in mesophyll cells was low compared with trichomes in epidermal cells (Figure 5) which might avoid lipid peroxidation and membrane damage in chloroplasts. A similar tolerance strategy consisting of metal compartmentation to avoid metal toxicity has been found in Erica andevalensis [14] and in other species [35-38]. Carotenoids were negatively 
affected by $\mathrm{Cu}$ treatments, as reported by other authors [39,40], suggesting that these pigments were more sensitive to $\mathrm{Cu}$-induced peroxidation. Peroxidase and catalase activities were used as stress markers since these enzymes may scavenge the high ROS production induced by high free metal cellular contents [13]. Once the metal is absorbed and accumulated in the cytosol, it may cause oxidative stress through the production of reactive oxygen species [6]. The free metal may be chelated with amino acids and then removed by compartmentation [2,27], avoiding further cell damages. Root peroxidase activity was increased at $100 \mu \mathrm{M} \mathrm{Cu}$ treatment, but it decreased at higher $\mathrm{Cu}$ concentration, making it difficult to conclude this enzyme might play a role in $\mathrm{Cu}$ tolerance. Some authors also proposed that an excess of $\mathrm{Cu}$ may decrease antioxidant capacity [1,41-44] Meanwhile, catalase activity certainly might be involved in the alleviation of oxidative stress caused by $\mathrm{Cu}$ (Table 1) in addition to other enzymes such as superoxide dismutases [45]. Malondialdehyde (MDA) is an indicator of oxidative damage in membrane lipids, and at the highest $\mathrm{Cu}$ concentration, an increase in MDA in leaves was found. Similar results were reported in other researches where the formation of free radicals by an excess of $\mathrm{Cu}$ react with membrane lipids to form lipid radicals and the cytotoxic MDA [40,46]. Present results suggest that even if E. australis may survive at a $\mathrm{Cu}$ excess of $200 \mu \mathrm{M}$ by acting as a metal excluder species, its mechanism for survival breaks down (or is not enough) at high external $\mathrm{Cu}$ concentrations (higher than $50 \mu \mathrm{M} \mathrm{Cu}$ ). At the threshold of $50 \mu \mathrm{M} \mathrm{Cu}$, the tolerance capacity is disrupted, and $\mathrm{Cu}$ enters into the cytoplasm and generates oxidative stress.

\section{Materials and Method}

\subsection{Plant Culture and $\mathrm{Cu}$ Treatments}

Seeds of Erica australis proceeding from Tinto River (SW Spain) sterilized in $0.3 \%$ Na-hypochlorite and washed 3 times with sterile distilled water and pre-treated with heat $\left(80^{\circ} \mathrm{C}\right.$ during $10 \mathrm{~min}$ ) to promote germination. Then seeds were sown into tubes filled with rockwool and transferred into 101 plastic containers with nutrient solution ( $\mathrm{pH} 4.0)$ containing (in $\mathrm{mM}$ ): $\mathrm{NO}_{3}{ }^{-}, 5 ; \mathrm{H}_{2} \mathrm{PO}_{4}{ }^{-}, 1 ; \mathrm{SO}_{4}{ }^{2-}, 2.5 ; \mathrm{K}^{+}, 4 ; \mathrm{Ca}^{2+}, 2 ; \mathrm{Mg}^{2+}, 1$. Micronutrients were supplied as prescribed in the Long Ashton nutrient formula [47], and Fe was provided as $4 \mathrm{mg} / 1 \mathrm{Fe}-\mathrm{EDDHA}$ (ethylenediamine di-2-hydroxyphenyl acetate ferric). Plants were cultivated in a growth chamber with cycles of $26-23^{\circ} \mathrm{C}$ (day-night temperature) and $16 \mathrm{~h}$ light $/ 8 \mathrm{~h}$ darkness. When plants were three months old, they were treated with different Cu concentrations ( $50 \mu \mathrm{M}, 100 \mu \mathrm{M}$ and $200 \mu \mathrm{M})$ as CuSO4. The control treatment contained $1 \mu \mathrm{M} \mathrm{Cu}$. These concentrations were selected after previous survival assays and according to soil $\mathrm{Cu}$ concentration found in the Riotinto mining area [12]. The nutrient solutions were continuously aerated with an aquarium air pump and renewed every 10 days to maintain a rather constant nutrient supply and metal concentration. The experiment was carried out for 30 days, and plants were weighed at a 10-day interval. All treatments had four replicates.

\subsection{Growth Measurements and Elements Concentration}

At the end of the experiment, plants were harvested, and plants were separated into roots, stems and leaves. Samples were washed once in tap water before being gently washed twice with distilled water and oven-dried at $70^{\circ} \mathrm{C}$ for $48 \mathrm{~h}$, and dry biomass was determined. Dried plant material was then milled and digested with a mixture of $\mathrm{HNO}_{3}$ and $\mathrm{H}_{2} \mathrm{O}_{2}$ [48]. Macro and micronutrients concentration in each plant part was determined by inductively coupled plasma atomic emission spectrometry (ICP-AES). The plant growth rate was assessed by fresh weight determinations every 10 days till the end of treatment (30 days). Water content (WC) in roots and shoots (leaves + stems) was calculated at harvest as $W C=(($ fresh weight - dry weight $) /$ fresh weight $) \times 100$. Plant shoot $/$ root ratios $(S / R)$ were calculated by dividing shoot fresh weight by its corresponding root fresh weight. 


\subsection{Determination of Biochemical Traits and $\mathrm{Cu}$ Localization by Scanning Electron Microscopy}

Chlorophylls $a$ and $b$ and carotenoids were extracted from young shoots with $90.5 \%$ methanol and determined according to Lichtenthaler and Buschmann [49]. The activity of peroxidase (POD) was measured in aliquots of crude extracts from shoots and roots in a reaction mixture containing $0.1 \mathrm{mM} \mathrm{H}_{2} \mathrm{O}_{2}$ and $20.0 \mathrm{mM}$ pyrogallol. The $\mathrm{H}_{2} \mathrm{O}_{2}$-dependent oxidation of the donor was followed at $430 \mathrm{~nm}$ (due to purpurogallin, $\varepsilon_{430 \mathrm{~nm}}=2.47 \mathrm{mM}^{-1} \mathrm{~cm}^{-1}$ ) as reported elsewhere [50]. The activity of catalase (CAT) was determined by measuring the disappearance of $\mathrm{H}_{2} \mathrm{O}_{2}$ following the decrease in absorbance at $240 \mathrm{~nm}$ following Aebi [51]. The reaction mixture contained $50 \mathrm{mM}$ potassium phosphate buffer ( $\mathrm{pH}$ 6.5), $1 \mathrm{mM}$ EDTA and $15 \mathrm{mM} \mathrm{H}_{2} \mathrm{O}_{2}$. Protein concentration in the extracts was determined according to Bradford [52]. Lipid peroxidation was determined by estimating malondialdehyde (MDA), which was quantified according to Heath and Packer [53]. To localize $\mathrm{Cu}$ in different tissues plants, E. australis treated with $50 \mu \mathrm{M} \mathrm{Cu}$ was observed with Cryo Scanning Electron Microscopy (SEM), and energy dispersive X-ray (EDX) analysis was performed. Roots and leaves were cut into small pieces and frozen in nitrogen slush $\left(-210^{\circ} \mathrm{C}\right)$, quickly transferred to the cryospecimen chamber, freeze fractured and etched at $-90^{\circ} \mathrm{C}$ for the time required to remove surface ice. Samples were Au coated and examined using a Zeiss DSM 960 at $-130^{\circ} \mathrm{C}$ coupled with an energy dispersive X-ray microanalyzer. The microscopy was operated at an acceleration voltage of $25 \mathrm{kV}$ with a beam current of $80 \mu \mathrm{A}$, a working distance of $12 \mathrm{~mm}$, beam penetration depth of 5-6 $\mu \mathrm{m}$ and spectra collection time over $50 \mathrm{~s}$. Analyses were carried out with a 10,000 $\times$ magnification. All semi-quantitative values were normalized excluding $\mathrm{C}, \mathrm{Au}$ and $\mathrm{O}$ [54] and were expressed as percent weight. All determinations were made for quadruplicates.

\subsection{Statistical Analysis}

Statistical analysis was performed with the Statsoft package v 6.12. The normality of the data was checked by Shapiro-Wilk test. A one-way analysis of variance (ANOVA) was used to detect significant differences between treatments, between $\mathrm{Cu}$ in plant tissues and parts, followed by Tukey's HSD as a post hoc test $(p<0.05)$. Data were tested for normality, and in some cases, logarithmically transformed data were used in order to get a normal distribution. When data did not achieve homogeneity, the Kruskal-Wallis non-parametric test was used. A correlation analysis (Pearson) was performed between the $\mathrm{Cu}$ concentration in the nutrient solution and the other elements in the different plant parts. Regression analysis was used to determine several models (linear and exponential equations) of the plant concentration-response curves exposed to different $\mathrm{Cu}$ concentrations.

\section{Conclusions}

The exposure of Erica australis to $200 \mathrm{Cu} \mu \mathrm{M}$ did not affect plant survival, but a $\mathrm{Cu}$ concentration beyond $50 \mu \mathrm{M} \mathrm{Cu}$ caused a reduction in plant growth, indicating a $\mathrm{Cu}$ toxicity stress that caused an increase in catalase content in roots and lipid peroxidation (MDA) in leaves. The species accumulated Cu mostly in the roots (exclusion strategy), avoiding metal translocation to the aerial parts, but the $\mathrm{Cu}$ excess induces a decrease in K. Even though metal translocation was limited by root fixation, the species presented a high $\mathrm{Cu}$ concentration in the leaves (above the $\mathrm{Cu}$ toxicity threshold of many other species) but without a significant reduction in chlorophylls content or deficiency in macro and micronutrients. The accumulation of $\mathrm{Cu}$ in the abaxial trichomes of leaf epidermal cells might provide additional tolerance to metal toxicity.

Author Contributions: Both authors have contributed equally to the article even if the writing of the manuscript was carried out by S.R.-O. Both authors have read and agreed to the published version of the manuscript.

Funding: This research received external funding from the Ramón Areces Foundation and the Andalucía Regional Govt. (RNM-3526). 
Data Availability Statement: The data that support the findings of this study are available from the corresponding author, upon reasonable request.

Acknowledgments: We thank Eduardo O. Leidi for the revision of the article and useful suggestions.

Conflicts of Interest: The authors declare no conflict of interest.

\section{References}

1. Rehman, N.; Maqbool, Z.; Peng, D.; Liu, L. Morpho-physiological traits, antioxidant capacity and phytoextraction of copper by ramie (Boehmeria nivea L.) grown as fodder in copper-contaminated soil. Environ. Sci. Pollut. Res. 2019, 26, 5851-5861. [CrossRef]

2. Kumar, V.; Pandita, S.; Sidhu, G.P.S.; Sharma, A.; Khanna, K.; Kaur, P.; Bali, A.S.; Setia, R. Copper bioavailability, uptake, toxicity and tolerance in plants: A comprehensive review. Chemosphere 2021, 262, 127810. [CrossRef] [PubMed]

3. Marschner, H. Mineral Nutrition of Higher Plants; Academic Press: London, UK, 1995.

4. Monni, S.; Salemaa, M.; White, C.; Tuittila, E. Copper resistance of Calluna vulgaris originating from the pollution gradient of a Cu-Ni smelter, in southwest Finland. Environ. Pollut. 2000, 109, 211-219. [CrossRef]

5. Kupper, H.; Götz, B.; Mijovilovich, A.; Küpper, F.C.; Meyer-Klaucke, W.E. Complexation and toxicity of copper in higher plants I. Characterization of copper accumulation, speciation, and toxicity in Crassula hemsii as a new copper accumulator. Plant Physiol. 2009, 151, 702-714. [CrossRef]

6. Angulo-Bejarano, P.; Puente-Rivera, J.; Cruiz-Ortega, R. Metal and metalloid toxicity in plants: An overview on molecular aspects. Plants 2021, 10, 635. [CrossRef]

7. Ernst, W.H.O.; Verkleij, J.A.C.; Schat, A. Metal tolerance in plants. Acta Bot. Neerl. 1992, 41, 229-248. [CrossRef]

8. Punz, W.F.; Sieghard, H. The response of roots of herbaceous plant species to heavy metals. Environ. Exp. Bot. 1993, 33, 85-98. [CrossRef]

9. Abreu, M.M.; Tavares, M.T.; Batista, M.J. Potential use of Erica andevalensis and Erica australis in phytoremediation of sulphide mine environments: São Domingos. Portugal. J. Geochem. Explor. 2008, 96, 210-222. [CrossRef]

10. Rodríguez, N.; Amils, R.; Jiménez-Ballesta, R.; Rufo, L.; de la Fuente, V. Heavy metal content in Erica andevalensis: An endemic plant from the extreme acidic environment of Tinto River and its soils. Arid. Land. Res. Manag. 2007, 21, 51-65. [CrossRef]

11. Monaci, F.; Leidi, E.O.; Mingorance, M.D.; Valdés, B.; Rossini Oliva, S.; Bargagli, R. Selective Uptake of Major and Trace Elements in Erica andevalensis, an Endemic Species to Extreme Habitats in the Iberian Pyrite Belt. J. Environ. Sci. 2011, 23, 444-452. [CrossRef]

12. Monaci, F.; Trigueros, D.; Mingorance, M.D.; Rossini Oliva, S. Phytostabilization potential of Erica australis L. and Nerium oleander L.: A comparative study in the Riotinto mining area (SW Spain). Environ. Geochem. Health 2020, 42, 2345-2360. [CrossRef] [PubMed]

13. Chmielowska-Bąk, J.; Deckert, J. Plant recovery after metal stress-A review. Plants 2021, 10, 450. [CrossRef] [PubMed]

14. Rossini-Oliva, S.; Mingorance, M.D.; Valdés, B.; Leidi, E.O. Uptake, localisation and physiological changes in response to copper excess in Erica andevalensis. Plant Soil 2010, 328, 411-420. [CrossRef]

15. Rufo, L.; Rodríguez, N.; de la Fuente, V. Plant communities of extreme acidic waters: The Rio Tinto case. Aquat. Bot. 2011, 95, 129-139. [CrossRef]

16. Rossini-Oliva, S.; Abreu, M.M.; Leidi, E.O. A review of hazardous elements tolerance in a metallophyte model species: Erica andevalensis. Geoderma 2018, 319, 43-51. [CrossRef]

17. Liu, D.; Kottke, I. Subcellular localization of copper in the root cells of Allium sativum by electron energy loss spectroscopy (EELS). Bioresour. Technol. 2004, 94, 153-158. [CrossRef] [PubMed]

18. Sharma, S.S.; Dietz, K.J.; Mimura, T. Vacuolar compartmentalization as indispensable component of heavy metal detoxification in plants. Plant Cell Environ. 2016, 39, 1112-1126. [CrossRef] [PubMed]

19. Lombardi, L.; Sebastiani, L. Copper toxicity in Prunus cerasifera: Growth and antioxidant enzymes responses of in vitro grown plants. Plant Sci. 2005, 168, 797-802. [CrossRef]

20. Vidal, C.; Larama, G.; Riveros, A.; Meneses, C.; Cornejo, P. Main molecular pathways associated with copper tolerance response in Imperata cylindrica by de novo transcriptome assembly. Plants 2021, 10, 357. [CrossRef]

21. Chen, C.T.; Chen, T.H.; Lo, K.F.; Chiu, C.Y. Effects of proline on copper transport in rice seedlings under excess copper stress. Plant Sci. 2004, 166, 103-111. [CrossRef]

22. Kabata-Pendias, A.; Pendias, H. Trace Elements in Soils and Plants; CRC Press: Boca Raton, FL, USA, 2011.

23. Lepp, N.W. Cycling of Copper in Woodland Ecosystem. In Copper in the Environment Part I: Ecological Cycling; Nriagu, J.O., Ed.; John Wiley \& Sons: New York, NY, USA, 1979; pp. 289-323.

24. Trigueros Vera, D. Respuesta de dos Especies Arbustivas (Erica australis y Nerium oleander) Frente a la Contaminación Derivada de la Actividad Minera en Riotinto. Ph.D. Thesis, Universidad de Sevilla, Seville, Spain, 2011. Available online: https://dialnet. unirioja.es/servlet/tesis?codigo=24663 (accessed on 25 May 2021). (In Spanish).

25. Schreiber, L.; Hartmann, K.; Skabs, M.; Zeier, J. Apoplastic barrier in roots: Chemical composition of endodermal and hypodermal cell wall. J. Exp. Bot. 1999, 50, 1267-1280. [CrossRef]

26. Nazir, F.; Hussain, A.; Fariduddin, Q. Hydrogen peroxide modulate photosynthesis and antioxidant systems in tomato (Solanum lycopersicum L.) plants under copper stress. Chemosphere 2019, 230, 544-558. [CrossRef] [PubMed] 
27. Nailo, A.; Meerdink, G.; Jayasena, V.; Sulaimn, A.Z.; Ajit, A.B.; Berta, G. A review on global metal accumulators-mechanism, enhancement, commercial application, and research trend. Environ. Sci. Pollut. Res. 2019, 26, 26449-26471. [CrossRef]

28. Thounaojam, T.C.; Panda, P.; Mazumdar, P.; Kumar, S.; Sharma, G.; Sahoo, L.; Sanjib, P. Excess copper induces oxidative stress and response of antioxidants in rice. Plant Physiol. Biochem. 2012, 53, 33-39. [CrossRef]

29. Shahid, M.; Pourrut, B.; Dumat, C.; Nadeem, M.; Aslam, M.; Pinelli, E. Heavy-metal-induced reactive oxygen species: Phytotoxicity and physico-chemical changes in plants. Rev. Environ. Contam. Toxicol. 2014, 232, 1-44.

30. Przedpelska-Wasowicz, E.M.; Wierzbicka, M. Gating aquaporins by heavy metals in Allium cepa L. epidermal cells. Protoplasma 2011, 248, 663-671. [CrossRef]

31. Rucińska-Sobkowiak, R. Water relations in plants subjected to heavy metal stress. Acta Physiol. Plant. 2016, 38, 257. [CrossRef]

32. Hall, J.L. Cellular mechanisms for heavy metal detoxification and tolerance. J. Exp. Bot. 2002, 53, 1-11. [CrossRef]

33. Ait Ali, N.M.; Bernal, P.; Ater, B. Tolerance and bioaccumulation of copper in Phragmites australis and Zea mays. Plant Soil 2002, 239, 103-111. [CrossRef]

34. Reichman, S.M. The Responses of Plants to Metal Toxicity: A Review Focusing on Copper, Manganese and Zinc; Australian Minerals \& Energy Environment Foundation: Melbourne, Australia, 2002; pp. 1-54.

35. Freeman, J.L.; Zhang, L.H.; Marcus, M.A.; Fakra, S.; McGrath, S.P.; Pilon-Smits, E.A.H. Spatial imaging, speciation, and quantification of selenium in the hyperaccumulator plants Astragalus bisulcatus and Stanleya pinnata. Plant Physiol. 2006, 1425, 124-134. [CrossRef] [PubMed]

36. Clemenes, S.; Ma, J.F. Toxic heavy metal and metalloid accumulation in crop plants and foods. Annu. Rev. Plant Biol. 2016, 67, 489-512. [CrossRef]

37. Krämer, U.; Grime, G.W.; Smith, J.A.C.; Hawes, C.R.; Baker, A.J.M. Micro-PIXE as a technique for studying nickel localization in leaves of the hyperaccumulator plant Alyssum lesbiacum. Nucl. Instrum. Methods Phys. Res. Sect. B 1997, 130, 346-350. [CrossRef]

38. Broadhurst, C.L.; Bauchan, G.R.; Murphy, C.A.; Tang, Y.-T.; Pooley, C.; Davis, A.P.; Chaney, R.L. Accumulation of zinc and cadmium and localization of zinc in Picris divaricata Vant. Environ. Exp. Bot. 2013, 87, 1-9. [CrossRef]

39. Macfarlane, G.R.; Burchett, M.D. Photosynthetic pigments and peroxidase activity as indicators of heavy metal stress in the grey mangrove, Avicennia marina (Forsk.) Vierh. Mar. Poll. Bull. 2001, 42, 233-240. [CrossRef]

40. Giannakoula, A.; Therios, I.; Chatzissavvidis, C. Effect of lead and copper on photosynthetic apparatus in Citrus (Citrus aurantium L.) plants. The role of antioxidants in oxidative damage as a response to heavy metal stress. Plants 2021, 10, 155. [CrossRef] [PubMed]

41. Luna, C.M.; Gonzalez, C.A.; Trippi, V.S. Oxidative damage caused by an excess of copper in oat leaves. Plant Cell Physiol. 1994, 35, $11-15$.

42. Mazhoudi, S.; Chaoui, A.; Ghorbal, M.H.; El Ferjani, E. Response of antioxidant enzymes to excess copper in tomate (Lycopersicon esculentum, Mill.). Plant Sci. 1997, 127, 129-137. [CrossRef]

43. Schützendübel, A.; Polle, A. Plant responses to abiotic stresses: Heavy metal-induced oxidative stress and protection by mycorhization. J. Exp. Bot. 2002, 53, 1351-1365. [CrossRef]

44. Alí, M.B.; Hahn, E.J.; Paek, K.Y. Copper-induced changes in the growth, oxidative metabolism, and saponin production in suspension culture roots of Panax ginseng in bioreactors. Plant Cell Rep. 2006, 25, 1122-1132. [CrossRef]

45. del Río, L.A.; Corpas, F.J.; López-Huertas, E.; Palma, J.M. Plant Superoxide Dismutases: Function under Abiotic Stress Conditions. In Antioxidants and Antioxidant Enzymes in Higher Plants; Gupta, D., Palma, J., Corpas, F., Eds.; Springer: Cham, Switzerland, 2018; pp. 1-26. [CrossRef]

46. Chaoui, A.; El Ferjani, E. Effects of cadmium and copper on antioxidant capacities, lignification and auxin degradation in leaves of pea (Pisum sativum L.) seedlings. Comptes Rendus Biol. 2005, 328, 23-31. [CrossRef] [PubMed]

47. Hewitt, E.J. Sand and water culture methods used in the study of plant nutrition. In Commonwealth Bureau of Horticulture and Plantation Crops, 2nd revised ed.; Technical Communication No. 22; East Malling, CAB: Farnham Royal, UK, 1966.

48. Mingorance, M.D.; Pérez-Vázquez, L.; Lachica, M. Microwave digestion method for the atomic determination of some elements in biological samples. J. Anal. Atom. Spectrom. 1993, 8, 853-858. [CrossRef]

49. Lichtenthaler, H.K.; Buschmann, C. Chlorophylls and carotenoids: Measurement and characterization by US-VIS spectrometry. Curr. Protoc. Food. Anal. Chem. 2001, 1, F4.3.1-F4.3.8. [CrossRef]

50. Jiménez, A.; Hernández, J.A.; de1 Rio, L.A.; Sevilla, F. Evidence for the presence of the ascorbate-glutathione cycle in mitochondria and peroxisomes of pea leaves. Plant Physiol. 1997, 114, 275-284. [CrossRef] [PubMed]

51. Aebi, H. Catalase in vitro. Method Enzym. 1984, 105, 121-126.

52. Bradford, M.M. A rapid and sensitive method for quantitation of microgram quantities of protein utilizing the principle of protein-dye-binding. Anal. Biochem. 1976, 72, 248-254. [CrossRef]

53. Heath, R.L.; Packer, L. Photoperoxidation in isolated chloroplast: I. Kinetics and stoichiometry of fatty acid peroxidation. Arch. Biochem. Biophys. 1968, 126, 189-198. [CrossRef]

54. León, V.; Rabier, J.; Notonier, R.; Barthélemy, R.; Moreau, X.; Bouraïma-Madjèbi, S.; Viano, J.; Pineau, R. Effects on three nickel salts on germinating sedes of Grevillea exul var. rubiginosa, an endemic serpentine Proteaceae. Ann. Bot. 2005, 95, 605-618. [CrossRef] [PubMed] 